\title{
EKG-gyöngyszem: tónusos-clonusos epilepsziás roham kimutatása implantábilis loop recorderrel
}

\author{
Tomcsányi János dr. ${ }^{1}$ - Nényei Zoltán dr. ${ }^{1}$ \\ Kelemen Anna dr. ${ }^{2}$. Kamondi Anita dr. ${ }^{2}$ \\ ${ }^{1}$ Budai Irgalmasrendi Kórház, Kardiológia, Budapest \\ ${ }^{2}$ Országos Klinikai Idegtudományi Intézet, Budapest
}

\begin{abstract}
A szerzők egy 52 éves nőbeteg esetét mutatják be, akinél a sorozatos syncopék hátterében generalizált tónusos-clonusos epilepsziás rohamok álltak, amit implantábilis loop recorder (ILR-) vizsgálat mozgási mútermékei alapján diagnosztizáltak. A beteg a beállított antiepileptikum hatására 9 hónapja panaszmentes.

Orv Hetil. 2019; 160(29): 1143-1145.
\end{abstract}

Kulcsszavak: implantábilis loop recorder, syncope, epilepszia

\section{ECG pearl: tonic-clonic seizure detected by implantable loop recorder}

\begin{abstract}
A 52-year-old woman is presented with repetitive transient loss of consciousness. Implantable loop recorder (ILR) recorded muscle artifacts during the generalized tonic-clonic seizures. Seizure was diagnosed and antiepileptic drug was started. The patient has been asymptomatic for 9 months.
\end{abstract}

Keywords: implantable loop recorder, syncope, seizure

Tomcsányi J, Nényei Z, Kelemen A, Kamondi A. [ECG pearl: tonic-clonic seizure detected by implantable loop recorder]. Orv Hetil. 2019; 160(29): 1143-1145.

(Beérkezett: 2019. február 24.; elfogadva: 2019. március 13.)

\section{Rövidítések}

$\mathrm{EKG}=$ elektrokardiográfia; ILR = (implantable loop recorder $)$ beültethető szívmonitor; GM = (grand mal) generalizált roham; $\mathrm{MR}=($ magnetic resonance $)$ mágneses rezonancia

\section{Esetismertetés}

Az 52 éves nőbeteget ismételt syncope miatt vizsgálták. A kardiológiai vizsgálatok (EKG, Holter és szívultrahang) strukturális szívbetegségre utaló eltérést nem mutattak. Az elhanyagolható számú supraventricularis extrasystolén kívül releváns ritmuszavar nem igazolódott. A beteget neurológus is látta, aki nem neurológiai etiológiájúnak véleményezte az eszméletvesztéseket. Ezért implantábilis loop recorder (ILR) beültetését kérték osztályunktól. A megelőző vizsgálatokat elfogadva a beültetés megtörtént. A betegnek a beültetés elött $6 \times$ volt synco- pés attakja. Az implantáció után 77 nappal éjszaka a beteg párja két alkalommal észlelte, hogy felesége „furcsán veszi a levegőt, és végtagjai begörcsöltek”. A feleségét nem tudta felébreszteni, de a készüléket aktiválta, majd tovább aludt. A felesége reggel mindkét combjában jelentkező izomlázat észlelt, egyébre nem emlékezett. A páciens aktiválta regisztrátum egyértelmú euritmiára szuperponálódó, kezdetben tónusos, majd clonusos görcsnek megfelelő, az izomaktivitásból eredő spike artefaktumokat mutatott (1. ábra). A fenti regisztrátumot egyértelmúen generalizált tónusos-clonusos epilepsziás rohamnak tartva, epileptológus neurológus véleményét kértük, aki az elsố neurológiai véleménnyel szemben szintén epilepsziát véleményezett, miután a beteggel egy munkahelyen dolgozó, korábban a beteg több rosszullétét látó szemtanú munkatársakat is kikérdezte. A beteg lamotrigin rágótablettára lett beállítva. A fokozatos dó- 

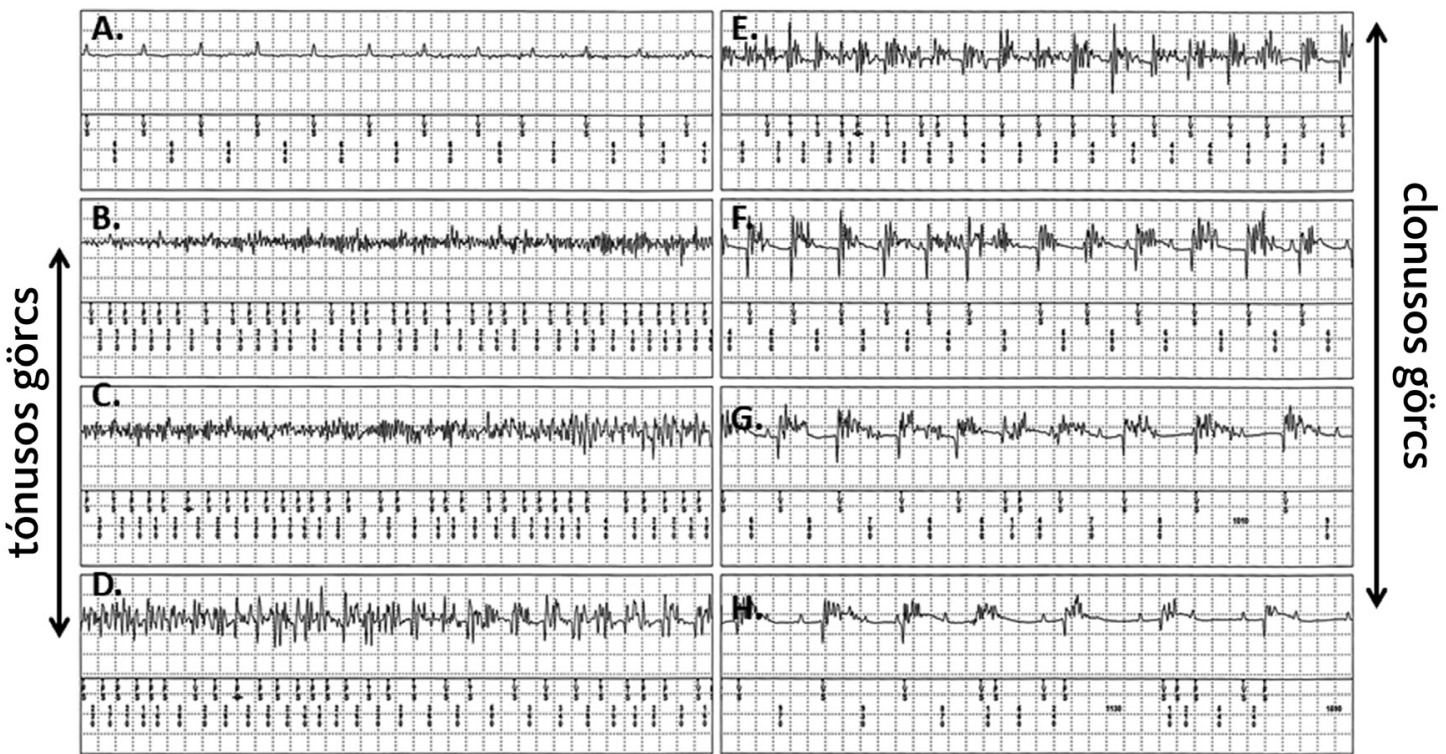

1. ábra

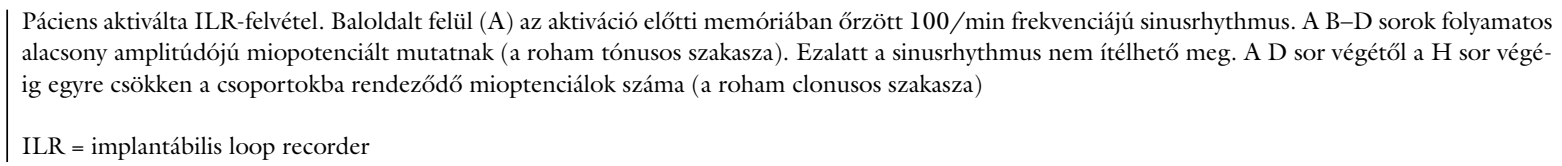

zisemelés közben elvégzett koponya-MR-vizsgálat kis bal oldali temporomedialis meningocephalocelét és piramiscsúcs-cephalocelét véleményezett. A betegnek az elmúlt 9 hónapban rosszulléte, syncopéja nem volt. Az MR-vizsgálat feltételezhetően az epilepsziáért felelős anatómiai szubsztrátumot is megtalálta (2. ábra).

\section{Megbeszélés}

A syncope etiológiájának tisztázása napjainkban is gyakran komoly problémát jelent. Ezt támasztja alá, hogy a legújabb európai ajánlás ún. 'syncope unit'-ok felállítását javasolja [1]. Az epilepsziás rosszullétek nem helyes elkülönítése a valódi cardialis syncopétől olyan probléma, amely számos fals diagnózist és kezelést okoz [2]. Az implantábilis loop recorder ebben is a segítségünkre tud lenni. Elsősorban olyan esetekben jön szóba, amelyekben az epilepszia kezelése ellenére változatlanul fennállnak a syncopés rosszullétek. Ezen monitorozási technika világított rá arra, hogy milyen magas a fals diagnózisok száma [3]. Esetünk ennek a problematikának egy másik oldalát világítja meg, amikor a beültetett loop recorderrel derült ki, hogy a beteg eszméletvesztéseit epilepszia okozza, amit az első neurológiai vizsgálat nem vetett fel. Ugyanakkor a rosszullétek szemtanúinak kikérdezése már a szívmonitor beültetése előtt kideríthette volna a diagnózist. Ezzel elkerülhető lett volna egy drága eszköz implantációja. Itt nem lehet eléggé hangsúlyozni a szemtanúk kikérdezésének fontosságát, mert a beteg autoanamnézise az amnézia miatt nem segít. Sajnos azonban azt is meg kell jegyezni, hogy a készülék páciensjelzés nélkül az epilepszia okozta miopotenciál-artefaktumok automata rögzítése tekintetében nem megbízható. A jelen esetben is csak azért derült rá fény, mert a hozzátartozó aktiválta a készüléket. Ez az eset/regisztrátum szép példája annak, hogy egy EKG-

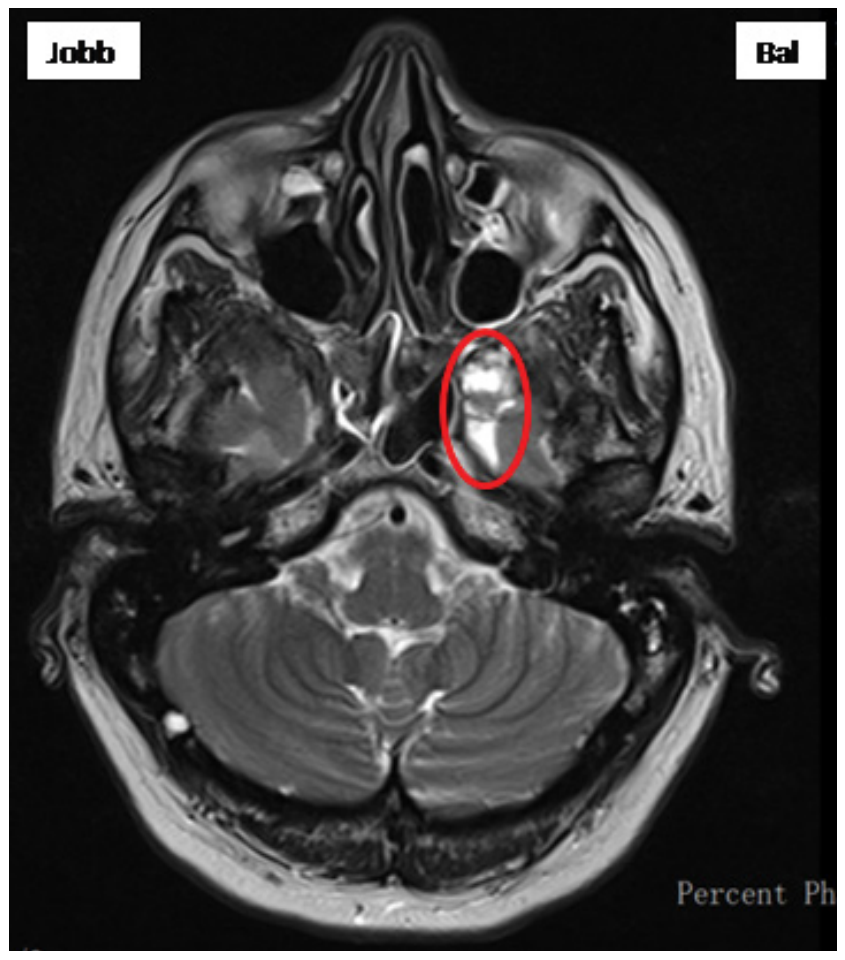

2. ábra

A T2-súlyozott MR-képen bal oldalon a temporalis basis a foramen ovale előtt egyenetlen kontúrú és kissé kimélyült, itt részben kis liquorjel-intenzitás, részben kis, inhomogén jelintenzitá sú cortexrészletek láthatók. Az eltérés kis temporomedialis meningoencephalocelének felel meg

$\mathrm{MR}=$ mágneses rezonancia 
artefaktum is tud bizonyos esetekben diagnosztikai értékkel bírni [4]. Végezetül meg kell jegyezni, hogy habár hazánkban is zajlik már jó pár éve ILR beültetése, és ennek kiváló eredményeiról mi is beszámoltunk [5], a lehetőségeink messze elmaradnak attól a számtól, amely indokolt lenne (egyötöde volt 2015-ben az európai átlagnak).

Anyagi támogatás: A szerzők a közlemény megírásával kapcsolatban anyagi támogatásban nem részesültek.

Szerzői munkamegosztás: T. J.: A cikk megírása, a szakmai tanácsadás menedzselése. N. Z.: Az ILR-implantáció elvégzése. Kelemen A.: Az epilepszia kezelése. Kamondi A.: Szakmai tanácsadás. A cikk végleges változatát valamennyi szerző elolvasta és jóváhagyta.

Érdekeltségek: A cikk megírásával, illetve tartalmával kapcsolatban a szerzőknek nincsenek érdekeltségeik.

\section{Irodalom}

[1] Brignole M, Moya A, de Lange FJ, et al. 2018 ESC Guidelines for the diagnosis and management of syncope. Eur Heart J. 2018; 39: 1883-1948.

[2] Zaidi A, Clough P, Cooper P, et al. Misdiagnosis of epilepsy: many seizure-like attacks have a cardiovascular cause. J Am Coll Cardiol. 2000; 36: 181-184

[3] Petkar S, Hamid T, Iddon P, et al. Prolonged implantable electrocardiographic monitoring indicates a high rate of misdiagnosis of epilepsy - REVISE study. Europace 2012; 14: 1653-1660.

[4] Ho RT, Wicks T, Wyeth D, et al. Generalized tonic-clonic seizures detected by implantable loop recorder devices: diagnosing more than cardiac arrhythmias. Heart Rhythm 2006; 3: 857861.

[5] Somlói M, Toldy-Schedel E, Nényei Z, et al. Role of implantable loop recorder in the clinical diagnosis of syncope: results of the introduction of an effective diagnostic tool. [Az implantálható loop recorder szerepe a syncope diagnosztikájában: egy hatékony módszer bevezetésének eredményei.] Orv Hetil. 2015; 156: 609-613. [Hungarian]

(Tomcsányi János dr., Budapest, Árpád fejedelem útja 7., 1027 e-mail: tomcsanyij@gmail.com)

\title{
XIX. Romhányi Orvostalálkozó - Lelkigyakorlat (manréza) orvosoknak Szár, 2019. augusztus 31. \\ Moderátor: Prof. Dr. Szelényi Zoltán
}

\author{
Délelőtti program \\ goo Szentmise \\ $10^{00}$ Üdvözlések \\ Németh Norbert (polgármester) \\ Prof. Dr. Kellermayer Miklós: „Gyógyszer az örökhalál ellen” \\ $10^{30}$ Márfi Gyula (veszprémi érsek): A betegség hordozása és gyógyitása - mint szakrális cselekedet \\ $11^{00}$ Legeza József (teológus, görög katolikus parókus): A magyar görögkatolikus egyház története, helyzete \\ $11^{30}$ Rieger Tibor (szobrászművész): A művészet szellemi alapjai a Koronázó palásttól napjainkig \\ Romhányi-emléktábla megkoszorúzása
}

\section{Délutáni program}

$14^{00}$ Prof. Dr. Poór Gyula: A kórház legyen több, mint kórház

$14^{30}$ Prof. Dr. Losonczy Hajna: Az immunglobulin profilaxis jelentősége krónikus lymphoid leukémiában

$15^{00}$ Prof. Dr. Emődy Levente: Romhányi György klinikopatológiai szemléletének példája az utódgenerációk számára

$15^{30}$ Prof. Dr. Kondákor István: A hívő orvos

Genzwein Ferenc sírjának megkoszorúzása 